\title{
Preface
}

This book began in my desire to evaluate the proposition that the 1920s witnessed the birth of a Soviet state technocracy. I was interested to learn whether we could discern, at the time of Lenin's death, for example, the outlines of an administrative system that displayed certain characteristics normally thought to be incompatible with the capricious politics of autocracy and dictatorship. In particular I wanted to know whether individuals professionally trained in technical and scientific fields had both important operational roles and the formal authority and power to allocate resources such as money and promotions from inside their various state administrative offices.

In principle, I had good reasons to think that throughout the modern history of Russia a transition to technocracy-that "happy" era, as Lenin put it, when engineers and agronomists would do most of the talking-was in process despite the tendency of politicians to exercise enormous political power arbitrarily. For one thing, Lenin himself often supported the idea that technicians and specialists, rather than politicians, should be in charge. For another, my previous research on the late nineteenth-century Imperial bureaucracy revealed that some government agencies were then moving markedly toward a technocratic mode of operation. And, although it would be a very long time in coming, it now seems evident that Mikhail S. Gorbachev's perestroika is the fruition of a historical process of administrative development. Gorbachev's policies have already opened new fields of influence and 
operation to many segments of Soviet society. Among these, certainly, is an administrative core consisting of a highly professionalized and specialized intelligentsia. Though they maintain some distance from the arbitrary and centralizing political traditions of the past half century, these officials are easily dirigiste enough to be described as technocratic.

My final and most important reason for thinking of the 1920s as an era of administrative transition emerged early in my research. It quickly became clear that if we look at the details of the structure and development of Soviet administration after the Revolution of 1917, we find technically shaped administrative offices growing rapidly and the numbers of technically trained administrators increasing. This phenomenon was of course important in itself for administrative change in Russia. But it had social implications as well. Because of the leviathan size and power of bureaucracy in Russia, the postrevolutionary transformation of offices inevitably produced a transformation of officials on a scale previously unknown anywhere in Europe. These administrative and social changes alone pointed me toward the need to explain both the origins of the Soviet state technocracy and the historical interaction between this technocracy and Russian society.

My research here is thus concerned principally with what I am calling the transitional generation of administrators in Russia and the USSR, that body of officialdom that crossed the revolutionary divide of 1917 and melded into the first generation of truly Soviet administrators. I am interested in these officials as such but also because they were witnesses to and participants in the process that transformed both the Russian bureaucracy and huge segments of Russian society.

Two of the most important arguments against the proposition that either the pre- or postrevolutionary eras in Russian or Soviet history saw the birth of technocracy are based on the tradition of arbitrary political intervention and the function of ideology as a source of countervailing values in administration. Each of these concepts has served as the thematic focus of countless histories of the Russian and Soviet states and their administrations. In the view of some, the importance of arbitrary and unpredictable political intervention in administrative affairs in the tsarist era is exceeded only by that of the raw and annihilating power of totalitarian political dictatorship in the Soviet era. The implied or expressed conclusion has inevitably been that such allencompassing, arbitrary politics and their accompanying ideologies render even a legalistic, Weberian bureaucracy impossible. A true technocracy, in which disinterested expertise and rationality combine with a legally secure bureaucracy, has thus seemed unattainable for Russia and the USSR. 
In my view, the repeated episodes of tsarist and Soviet political intervention in civil administrative affairs are significant in the broad, long-run sense that politics is important in every kind of organization. The control of human organizations always requires power. I think the crucial issue for Soviet history is whether political intervention can be shown to work consistently and effectively against the influence of technocrats in decisions important to the organization, such as hiring, firing, and the allocation of promotions and internal resources. One can easily show that political intervention does deflect the impact of technocrats in specific administrative decisions and selected examples of other bureaucratic behavior, but there is little evidence, in the history of either Russia or the USSR, that such intervening was systematically done over considerable periods of time for the bulk of the civil administration. Thus, in this book, I focus principally not on the exceptional episodes of political intervention but on the typical or normal office and official as I try to characterize patterns of change across time.

Ideology, specifically Marxist-Leninist ideology on the one hand and tsarist-Russian cultural values on the other, has certainly played a powerful countervailing role in the development of Russian and Soviet technocratic behavior. Since this statement is equally true for the twentieth century and for the nineteenth, I look carefully at the historical background, or patrimony of social and political behavior, which the state administration confronted in the revolutionary era.

Briefly, the evidence that the 1920s saw the nascence of a Soviet technocracy can be divided into three major categories: (1) that concerned with the structural transformation from generalist to specialist bureaucracy, which began as early as the era of Alexander I and proceeded rapidly after 1917; (2) that showing the inexorably increasing numbers and progressively elevated roles of specialists, a notable process in the second half of the nineteenth century, which took off rapidly after 1917; (3) that of the ever-increasing bureaucratization which, in Russia, was an inevitable consequence of the extension of government further and further into the details of social organization.

None of these fields of evidence alone suffices to sustain the conclusion that the post-1917 era saw the beginning of Soviet technocracy. Indeed, even taken together they do not furnish us with enough information to evaluate the process, because such major factors as the social and political roles of the nobility, the peasantry, and the Communist Party must also be studied. What we do find, however, is that a consideration of the complex interaction of these factors across the historical landscape of nineteenth- and twentieth-century Russia enables us to understand what technocracy means in the modern USSR, just as it equips us better to understand the social implications of admin- 
istrative change and the structural thrust of state administration into the future.

In part because this book is fundamentally a large-scale social history and in part because of the nature of the information upon which it is based, many of the arguments presented here will rely on numbersof people and of events-as well as on relative scales and orders of events. Although much of the analysis is therefore quantitative, I have attempted throughout to use techniques that are readily understood by the reader unversed in such analysis.

The list of institutions and persons to whom I am indebted for help in the preparation of this book is a long one. I am constrained, therefore, to acknowledge individually only a few of them, either for direct assistance in development of the research or, often, for unflagging interest and support of a long and sometimes frustrating project.

Among those who read and commented on the manuscript, I am especially grateful to Susan R. Carlton, Robert W. Davies, J. Arch Getty, John J. Markovic, Walter M. Pintner, and William G. Rosenberg. For help in the preparation of the text, I offer a special note of thanks to Anisa Miller-Pogacar, my colleague Bernard Sternsher, and the staff of Cornell University Press-especially my copy editor, Patricia Sterling, and my editor, John G. Ackerman.

Among those who provided general comments, suggestions, and sometimes badly needed moral support, I include John A. Armstrong, Jean Bonamour, Adam Bromke, William J. Hudson, and Michel Lesage together with his colleagues at the National Center for Scientific Research in Ivry, France.

Soviet colleagues to whom I am particularly indebted include V. Z. Drobizhev, Ivan D. Koval'chenko, Sergei Miakushev, and Iurii A. Poliakov and his associates at the Institute of History of the Academy of Sciences of the USSR.

American professional librarians are generally so competent and helpful that it is impossible to single out any for particular thanks and praise in spite of the fact that I relied upon many of them again and again. In Moscow, I benefited from the professional standards of the staff at the Institute for Scientific Study in the Social Sciences. In Paris, I was fortunate to be able to rely for assistance on the excellent staff at the Library for International Contemporary Documentation.

Obviously a project of this kind would be impossible without generous support for research from public and private foundations. In this case, while it is important to note that my findings do not necessarily represent their views, I am happy to acknowledge the assistance of the Academy of Sciences of the USSR, the American Council of Learned 
Societies, the International Research and Exchanges Board, the National Endowment for the Humanities, and, last but certainly not least, the Faculty Research Committee and the Department of History of Bowling Green State University.

The lines from Boris Pasternak's "On Early Trains" are quoted from Pasternak's Poems, trans. Eugene M. Kayden (Ann Arbor: University of Michigan Press, 1959). I am grateful for permission to reprint them.

DON K. ROWNEY

Toledo, Ohio 



\section{TRANSITION TO}

TECHNOCRACY 
